\title{
Detection of Tilapia Lake Virus (TiLV) in Healthy Fish from the Pre-Existing Disease Environment Using Different RT-PCR Methods
}

\author{
Patharapol Piamsomboon ${ }^{1}$, Janenuj Wongtavatchai ${ }^{1, *}$ (i)
}

${ }^{1}$ Chulalongkorn University, Faculty of Veterinary Sciences, Department of Veterinary Medicine, Bangkok 10330, Thailand.

\section{How to cite}

Piamsomboon, P., Wongtavatchai, J. (2021). Detection of Tilapia Lake Virus (TiLV) in healthy fish from the pre-existing disease environment using different RT-PCR methods. Turkish Journal of Fisheries and Aquatic Sciences, 21, $205-209$. http://doi.org/10.4194/1303-2712-v21_4_05

\section{Article History}

Received 24 December 2020

Accepted 13 January 2021

First Online 14 January 2021

Corresponding Author

Tel.: +6622189591

E-mail: janenuj.w@chula.ac.th

\section{Keywords}

Seabass

Tilapia

Virus

\begin{abstract}
We investigated the presence of TiLV in different fish species from the water reservoir that TiLV was previously reported. The virus was detected in healthy wild tilapia (Oreochromis niloticus) and farmed barramundi (Lates calcarifer) that shared water supply. Detection of TiLV was performed using three RT-PCR assays. Semi-nested RTPCR detected 9 positives, while the nested and one-step RT-PCR produced 7 and 4 positives, respectively. This study shows evidence that TiLV found in these two fish species is associated with the virus circulating in close proximity environment, nevertheless, it is deficient to indicate disease infection in these asymptomatic fish.
\end{abstract}

\section{Introduction}

Tilapia lake virus (TiLV), an emerging disease of tilapia, was first reported in Israel in 2011 (Eyngor et al., 2014). Subsequently, the disease was reported in tilapia culture regions worldwide, including Asia, Africa, South America (OIE, 2018) and most recently in the USA in 2019 (Ahasan et al., 2020). TiLV is designated to the family Amnoonviridae, a new genus Tilapinevirus and Tilapia tilapinevirus species (ICVT, 2018). The virus contains a negative-sense, single-stranded RNA (-ssRNA) and icosahedron envelop with the size of 55-100 nm diameter (Eyngor et al., 2014). TiLV was reported a causative agent of mass mortality within a month after transfer from the hatchery to the grow-out facility (Surachetpong et al., 2017). However, TiLV has also been detected in other fish species without clinical signs, such as wild river carp (Barbonymus schwanenfeldii) (Abdullah et al., 2018) and giant gourami (Osphronemus goramy) (Chiamkunakorn et al., 2019).

In the past decade, the production of barramundi or Asian seabass (Lates calcarifer) in Thailand has gradually increased from 12.5 metric tons in 2007 to 20.5 metric tons in 2017, while the Nile tilapia (Oreochromis niloticus) is also a major cultured fish species that shares a common cultured area (DOF, 2017). Recently, several viruses have been reported in both fish species, including betanodavirus causing viral nervous necrosis (VNN) disease (Glazebrook et al., 1990; Keawcharoen et al., 2015), and iridovirus causing infectious spleen and kidney necrosis virus (ISKNV) (Suebsing et al., 2016; Thanasaksiri et al., 2019). 
As recommended by the World Organization for Animal Health (OIE), the confirmatory test methods for TiLV detection are one step RT-PCR (Eyngor et al., 2014), nested RT-PCR (Tsofack et al., 2017) and semi-nested RT-PCR (Dong et al., 2017); however, validation of these three methods are suggested (OIE, 2018). We compared the TiLV detection using these three RT-PCR methods in fish species from the water source where TiLV has been detected. In addition, the TiLV detection was extended to farmed barramundi locating in close proximity to the TiLV-PCR positive wild fish.

\section{Materials and Methods}

\section{Fish Sample}

Observation for TiLV in freshwater fish residing in the natural reservoir was conducted from December 2019 to February 2020 in Chachoengsao province where TiLV was previously reported in farmed tilapia (Surachetpong et al., 2017). Three fish species, a total of 50 fish were collected from an irrigation canal $\left(13^{\circ} 29^{\prime} 08^{\prime \prime} \mathrm{N} 100^{\circ} 53^{\prime} 04^{\prime \prime} \mathrm{E}\right)$. Samples were Nile tilapia, climbing perch (Anabas testesdineus), and snakeskin gourami (Trichogaster pectoralis). In addition, two barramundi farms supplied with the same irrigation canal were sampled (10 barramundi/farm) for RT-PCR detection.

\section{Sample Preparation and RNA Extraction}

Fish were euthanized by immersion with $100 \mathrm{mgL}^{-}$ ${ }^{1}$ clove oil (Aquanes ${ }^{\circledR}$, Better Pharma, Thailand). The liver from each fish was collected. The tissue was kept in absolute ethanol at $-20^{\circ} \mathrm{C}$ before to RNA extraction and PCR analysis. A total of $60-80 \mathrm{mg}$ of tissue was prepared for total RNA extraction using the Trizol reagent (Invitrogen, USA) based on the manufacturer's protocols, followed by RNA quantification with Qubit 3 Fluorometer ${ }^{\circledR}$ and Qubit $^{\circledR}$ RNA assay kit (Invitrogen, USA). Samples of the extracted RNA with a RNA yield of 50-100 ng $\mathrm{LL}^{-1}$ were used for the RT-PCR amplifications.

\section{Detection of TiLV by RT-PCR}

Detection of TiLV was performed by the one step RT-PCR as described by Eyngor et al. (2014) using the 7450/150R/ME2 (5'-TATCACGTGCGTACTCGTTCAGT-3') and ME1 (5'-GTTGGGCACAAGGCATCCTA-3') primers, giving expected amplicon sizes of $250 \mathrm{bp}$. The RT-PCR mixture was composed of $12.5 \mu \mathrm{L}$ of $2 \mathrm{X}$ reaction mix, 0.5 $\mu \mathrm{L}$ of forward and reverse primer $(10 \mu \mathrm{M}), 1 \mu \mathrm{L}$ of SuperScript $^{\mathrm{TM}}$ III RT/Platinum ${ }^{\mathrm{TM}}$ Taq Mix (Invitrogen, USA), $2 \mu$ of RNA template (100-200 ng), and nucleasefree water to make a final volume of $25 \mu \mathrm{L}$. Thermocycling (Biometra, Göttingen, Germany) was performed at $50{ }^{\circ} \mathrm{C}$ for $30 \mathrm{~min}$ for the first stage RT reaction to form cDNA followed by the second stage qPCR of $35 \mathrm{cycles}$ at $94^{\circ} \mathrm{C}$ for $30 \mathrm{~s}, 60^{\circ} \mathrm{C}$ for $30 \mathrm{~s}$, and $72^{\circ} \mathrm{C}$ for $30 \mathrm{~s}$. The $415 \mathrm{bp}$ gene fragment of the TiLV gene segment (Integrated DNA Technologies, Singapore) was used as a positive control and no template (nucleasefree water) was used as the negative control.

The nested and semi-nested RT-PCR detection of TiLV were also applied in all extracted RNA samples to compare the result. The nested RT-PCR was conducted using the Nested ext-1 (5'-TATGCAGTACTTTCCCTGCC$\left.3^{\prime}\right)$ and Nested ext-2 (5'-TTGCTCTGAGCAAGAGTACC-3') primers followed by the 7450/150R/ME2 and ME1 primers (Tsofack et al., 2017). For semi-nested RT-PCR, the primers Nested ext-1 and ME1 were used for the first step and the primers 7450/150R/ME2 and ME1 were used for the second step PCR (Dong et al., 2017). The first step RT-PCR mixture was as described above and the second step PCR was performed in a final volume of $25 \mu \mathrm{L}$ containing $12.5 \mu \mathrm{L}$ of $2 \mathrm{X}$ DreamTaq PCR Master Mix (Thermo Fisher Scientific, USA), $0.5 \mu \mathrm{L}$ of 10 $\mu \mathrm{M}$ forward and reverse primers, $1 \mu \mathrm{L}$ of the first round RT-PCR product, and $10.5 \mu \mathrm{L}$ nuclease-free water. The same thermocycling protocol was as applied, except the cycle was decreased to 25 cycles for both steps. The expected amplicon size for both methods was $250 \mathrm{bp}$. All amplified samples were purified with a Nucleospin Gel Extraction kit (Macherey-Nagel, Düren Germany), cloned into the pGEM-T easy vector, and submitted for DNA sequencing (Macrogen, Republic of Korea). The nucleotide sequence was aligned and compared with TiLV sequences available in the NCBI database using BLASTn search (https://blast.ncbi.nlm.nih.gov/Blast.cgi).

\section{Results and Discussion}

\section{Detection of TiLV in Healthy Fish}

A total of 70 healthy juvenile fish were tested, including 29 samples of Nile tilapia, 12 samples of climbing perch, 9 samples of snakeskin gourami collected from the natural water reservoir, and 20 samples of farmed barramundi (Supplementary table). From these, TiLV was detected in 7 Nile tilapia samples and in 2 barramundi samples (Figure 1). The farmed barramundi samples were examined because they shared a common water source with the tilapia that found to be TiLV positive. Some viral pathogens are known to be able to infect both tilapia and barramundi, including VNN (Glazebrook et al., 1990; Bigarré et al., 2009) and ISKNV (Suebsing et al., 2016; Thanasaksiri et al., 2019). Although the risk factor of TiLV occurrence is not well-documented, it may share similar characteristics with closely related aquatic orthomyxoviruses, such as infectious salmon anemia virus (ISAV). The virus transmits between adjacent sites through water, fish movement, parasites and wild fish (OIE, 2019). On the contrary, an experimental transmission with intraperitoneal injection (I.P.) of TiLV showed that barramundi was not susceptible, and the virus was undetectable in liver tissues at $5 \mathrm{~d}$ post challenge (Jaemwimol et al., 2018). Even so, the 
Table 2. TiLV detection in wild Nile tilapia (Oreochromis niloticus, $n=29$ ), Climbing perch (Anabas testesdineus, $n=12$ ), snakeskin gourami (Trichogaster pectoralis, $\mathrm{n}=9$ ) and farmed barramundi (Lates calcalifer, $\mathrm{n}=20$ )

\begin{tabular}{lc}
\hline Samples & TiLV RT-PCR result* \\
\hline Collection Site 1 & $2 / 5$ \\
$\quad$ Nile tilapia & $0 / 5$ \\
Climbing perch & \\
Collection Site 2 & $5 / 5$ \\
$\quad$ Nile tilapia & $0 / 3$ \\
Climbing perch & $0 / 2$ \\
Snakeskin gourami & \\
Collection Site 3 & $0 / 6$ \\
Nile tilapia & $0 / 4$ \\
Snakeskin gourami & \\
Collection Site 4 & $0 / 10$ \\
$\quad$ Nile tilapia & \\
Collection Site 5 & $0 / 3$ \\
Nile tilapia & $0 / 4$ \\
Climbing perch & $0 / 3$ \\
Snakeskin gourami & $2 / 20$ \\
Farmed barramundi &
\end{tabular}

*Semi-nested RT-PCR (Dong et al., 2017)

transmission study in rainbow trout (Onchrhychus mykiss) with ISAV Atlantic salmon (Salmo salar) isolate revealed unsuccessful transmission via I.P. challenge whilst the transmission was achieved by cohabitation with the ISAV-infected salmon, mimicking the natural route of exposure (Snow et al., 2001a; Snow et al., 2001b).

This is the first report of TiLV detection in farmed barramundi and all TiLV positive samples in the present study showed $100 \%$ nucleotide sequence identity, both from barramundi (Thailand_BA_2019) and Nile tilapia (Thailand_NT_2019). The 250 bp sequence alignment of the TiLV fragment is shown in Figure 2. A BLASTn search of the $\mathrm{NCBI}$ database revealed $98.8 \%$ sequence similarity with the genome segment 3 of the Israeli isolate (Til-4-2011; GenBank accession no. KU751816.1). One barramundi sample gave an amplified product from a single step PCR, potentially indicating a substantial viral load in the tested tissue.

Also, detection of TiLV genomes in asymptomatic fish have been reported globally, such as in wild tilapia in Lake Victoria, Africa (Mugimba et al., 2018), wild river carp in Timah Tasoh Lake, Malaysia (Abdullah et al., 2018), cultured tilapia at fingerling and juvenile stages in Peru (Pulido et al., 2019), and in the adult stage in Thailand (Senapin et al., 2018). Natural outbreaks of TiLV infection associated with high mortalities mostly occur in fingerling and juvenile stages of tilapia (Eyngor et al., 2014; Ferguson et al., 2014; Surachetpong et al., 2017). From this fact, there is a possibility of TiLV inhabiting an aquatic environment and only affecting the susceptible young population under particular circumstances, such as an abrupt environmental change. In order to describe the disease condition, additional diagnosis including viral isolation and pathology are required with the positive PCR result.

\section{Comparison Between RT-PCR Methods for Detection of TiLV}

Three OIE cited RT-PCR assays were used to detect TiLV in our study. Among 70 healthy fish of 4 species, the one step RT-PCR revealed 4 positive samples, while the nested and semi-nested RT-PCR yielded 7 and 9 positive samples, respectively. The samples showed negative results in one step RT-PCR but yielding positive results in other two methods may indicate a latent or carrier status of those fish (Senapin et al., 2018). TiLV detection in apparently healthy (asymptomatic) fish may suggest low viral load in the fish tissues, therefore, screening of TiLV in healthy or wild fish without clinical symptoms should not rely solely on one step RT-PCR. Nevertheless, amplification error of samples detected by nested RTPCR in our study may be resulted from the mismatch of the Nested ext-2 primer with the mRNA sequence of Nile tilapia (Dong et al., 2017).

\section{Conclusion}

Polyculture systems and clustering of aquaculture farms in one area are commonly found in many parts of the world, and would facilitate the movement of viruses, including TiLV, between fish species or farms. The present study detected TiLV in tilapia and barramundi that were reared in the same vicinity and shared a water source. Only semi-nested, nested, or higher sensitivity PCR assays are recommended for testing asymptomatic individuals. Nevertheless, the pathological and transmission potential of TiLV in PCR-positive asymptomatic fish cannot be confirmed solely on the detection of the viral genome. Histopathology or viral isolation should be included to confirm a positive case. 


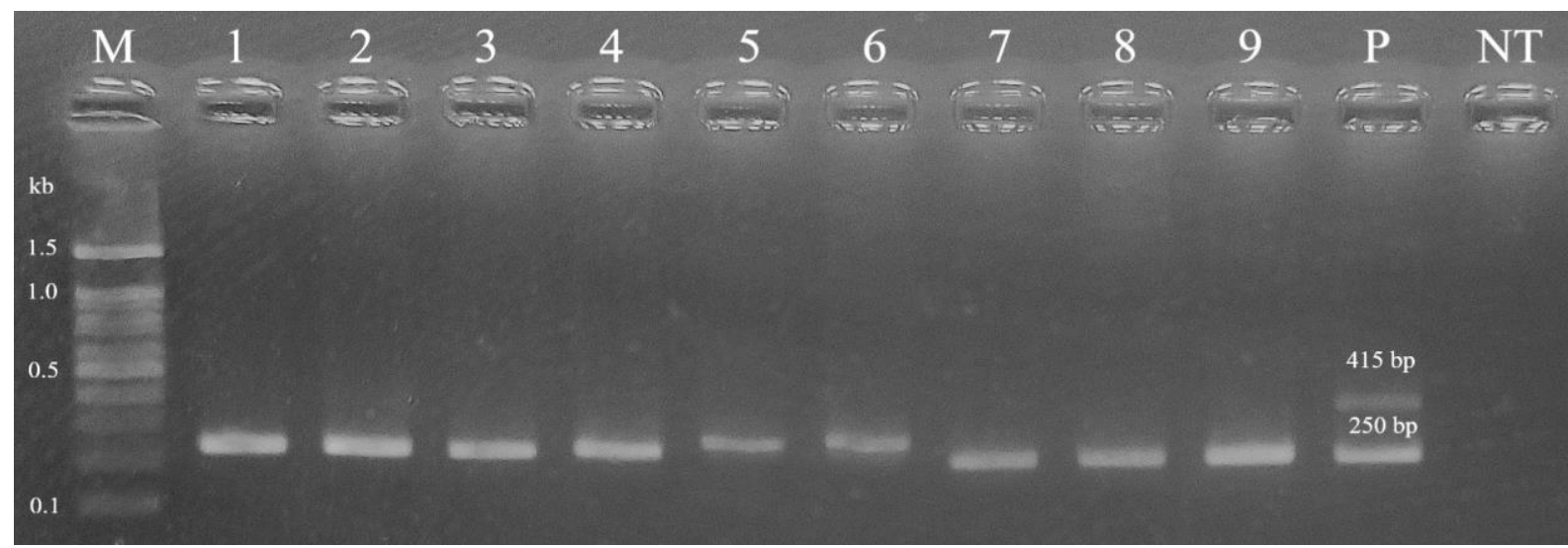

Figure 1. TiLV detection of samples obtained from Nile tilapia in the natural reservoir (Lane 1-7) and farmed barramundi (Lane 8 - 9) using semi-nested RT-PCR. M, 100 bp DNA ladder; NT, negative control; P, positive control.

Israel_KU751816_2011 TATCACGTGCGTACTCGTTCAGTATÄAGTTCTCTTGCCTCTTGGTCAAGACCACACTCCTCACCGCAGGCGAGGAAC̈TTTGAGCACTCGA 90 NT_Inapparent_2017 TATCACGTGCGTACTCGTTCAGTATAAGCTCTCTTGCCTCTTGGTCAAGACCACACTCCTCACCACAGGCGAGGAACTTTGAGCACTCGA 90 Thailand_BA_2019 TATCACGTGCG-ACTCGTTCAGTATGAGTTCTCTTGCCTCTTGGTCAAGACCACACTCCTCACCGCAGGCGAGGAATTTTGAGCACTCGA 89 Thailand_NT_2019 TATCACGTGCG-ACTCGTTCAGTATGAGTTCTCTTGCCTCTTGGTCAAGACCACACTCCTCACCGCAGGCGAGGAATTTTGAGCACTCGA 89 AGAATCCATATTGCCTCTTTAGCTCAGCTGTT̄TCCTTGGATATGTCCGCAAGTCTGGGTGGTGCCACCCACTCAATACGAGGCTTCGGĞ̈ 180
AGAACCCATATTGCCTCTTTAGCTCAGCTGTCTCCTTGGATATGTCCGCAAGTCTGGGTGGTGCCACCCACTCGATACGAGGCTTCGGGC 180
AGAATCCATATTGCCTCTTTAGCTCAGCTGTCTCCTTGGATATGTCCGCAAGTCTGGGTGGTGCCACCCACTCAATACGAGGCTTCGGAC 179
AGAATCCATATTGCCTCTTTAGCTCAGCTGTCTCCTTGGATATGTCCGCAAGTCTGGGTGGTGCCACCCACTCAATACGAGGCTTCGGAC 179 CACTCTTTGGATGTGGTAGTTCCAATAGCCGTTCCCTTAGCTCAGCATCGTAGGATGCCTTGTGCCCAAC 250 CACTCTTTGGATGTGGTAGTTCAAATAGCCGTTCCCTTAGCTCAGCATCGTAGGATGCCTTGTGCCCAAC 250 CACTCTTTGGATGTGGCAGTTCCAATAGCCGTTCCCTTAGCTCAGCATCGTAGGATGCCTTGTGCCCAAC 249 CACTCTTTGGATGTGGCAGTTCCAATAGCCGTTCCCTTAGCTCAGCATCGTAGGATGCCTTGTGCCCAAC 249

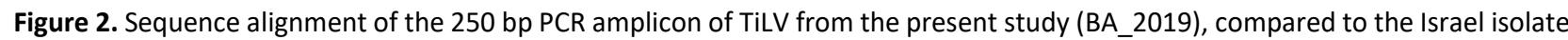
(Israel_KU751816_2011) and the Thai isolate obtained from healthy tilapia in 2017 (NT_Inapparent_2017; Senapin et al., 2018). Gray highlight indicates the different nucleotide between the present isolates and other two strains. Bold letter indicates the different nucleotide between the present isolates and NT_Inapparent_2017.

\section{Ethical Statement}

Not applicable

\section{Funding Information}

This work was supported by Chulalongkorn University, Thailand, under the Veterinary Science Research Fund.

\section{Author Contribution}

Patharapol Piamsomboon: Funding acquisition, conceptualization, investigation and drafting the original manuscript. Janenuj Wongtavatchai: Conceptualization, provided critical comments and final approval of the manuscript.

\section{Conflict of Interest}

The authors declare no conflict of interest.

\section{Acknowledgments}

The authors would like to thank the Office of Research Affairs, Chulalongkorn University for English editorial services and the Veterinary Pharmacology \& Stemcell Research Laboratory, Chulalongkorn University, for a technical advice.

\section{References}

Abdullah, A., Ramly, R., Ridzwan, M. S. M., Sudirwan, F., Abas, A., Ahmad, K., Murni, M., \& Kua, B. C. (2018). First detection of tilapia lake virus (TiLV) in wild river carp (Barbonymus schwanenfeldii) at Timah Tasoh Lake, Malaysia. Journal of Fish Diseases, 41(9), 1459-1462.

Ahasan, M. S., Keleher, W., Giray, C., Perry, B., Surachetpong, W., Nicholson, P., Al-Hussinee, L., Subramaniam, K., \& Waltzek, T. B. (2020). Genomic Characterization of Tilapia Lake Virus Isolates Recovered from Moribund Nile Tilapia (Oreochromis niloticus) on a Farm in the United States. Microbiology Resource Announcements, 9(4). 
Bigarré, L., Cabon, J., Baud, M., Heimann, M., Body, A., Lieffrig, F., \& Castric, J. (2009). Outbreak of betanodavirus infection in tilapia, Oreochromis niloticus (L.), in fresh water. Journal of Fish Diseases, 32(8), 667-673.

Chiamkunakorn, C., Machimbirike, V. I., Senapin, S., Khunrae, P., Dong, H. T., \& Rattanarojpong, T. (2019). Blood and liver biopsy for the non-destructive screening of tilapia lake virus. Journal of Fish Diseases, 42(11), 1629-1636.

DOF. (2017). Fisheries Statistics of Thailand. Ministry of Agriculture and Cooperatives. https://www.fisheries.go.th/strategy-stat/documentpublic

Dong, H., Siriroob, S., Meemetta, W., Santimanawong, W., Gangnonngiw, W., Pirarat, N., Khunrae, P., Rattanarojpong, T., Vanichviriyakit, R., \& Senapin, S. (2017). Emergence of tilapia lake virus in Thailand and an alternative semi-nested RT-PCR for detection. Aquaculture, 476, 111-118.

Eyngor, M., Zamostiano, R., Tsofack, J. E. K., Berkowitz, A., Bercovier, H., Tinman, S., Lev, M., Hurvitz, A., Galeotti, M., \& Bacharach, E. (2014). Identification of a novel RNA virus lethal to tilapia. Journal of clinical microbiology, 52(12), 4137-4146.

Ferguson, H., Kabuusu, R., Beltran, S., Reyes, E., Lince, J., \& Del Pozo, J. (2014). Syncytial hepatitis of farmed tilapia, Oreochromis niloticus (L.): a case report. Journal of Fish Diseases, 37(6), 583-589.

Glazebrook, J., Heasman, M., \& De Beer, S. (1990). Picorna-like viral particles associated with mass mortalities in larval barramundi, Lates calcarifer Bloch. Journal of Fish Diseases, 13(3), 245-249.

ICTV. (2018). Virus taxonomy: 2018b release. International committee on taxonomy of viruses. https://talk.ictvonline.org/taxonomy.

Jaemwimol, P., Rawiwan, P., Tattiyapong, P., Saengnual, P., Kamlangdee, A., \& Surachetpong, W. (2018). Susceptibility of important warm water fish species to tilapia lake virus (TiLV) infection. Aquaculture, 497, 462468.

Keawcharoen, J., Techangamsuwan, S., Ponpornpisit, A., Lombardini, E., Patchimasiri, T., \& Pirarat, N. (2015). Genetic characterization of a betanodavirus isolated from a clinical disease outbreak in farm-raised tilapia Oreochromis niloticus (L.) in Thailand. Journal of Fish Diseases, 38(1), 49-54.

Mugimba, K., Chengula, A., Wamala, S., Mwega, E., Kasanga, C., Byarugaba, D., Mdegela, R., Tal, S., Bornstein, B., \&
Dishon, A. (2018). Detection of tilapia lake virus (Ti LV) infection by PCR in farmed and wild Nile tilapia (Oreochromis niloticus) from Lake Victoria. Journal of Fish Diseases, 41(8), 1181-1189.

OIE. (2018). Technical disease cards: Tilapia Lake Virus (TiLV) A Novel Orthomyxo-Like Virus.

https://www.oie.int/fileadmin/Home/eng/Internationa _Standard_Setting/docs/pdf/A_TiLV_disease_card.pdf

OIE. (2019). Manual of Diagnostic Tests for Aquatic Animals: Infection with Infectious Salmon Anaemia Virus. https://www.oie.int/fileadmin/Home/eng/Health_stan dards/aahc/2010/chapitre_isav.pdf

Pulido, L. L. H., Mora, C. M., Hung, A. L., Dong, H. T., \& Senapin, S. (2019). Tilapia lake virus (TiLV) from Peru is genetically close to the Israeli isolates. Aquaculture, 510, 61-65.

Senapin, S., Shyam, K., Meemetta, W., Rattanarojpong, T., \& Dong, H. T. (2018). Inapparent infection cases of tilapia lake virus (TiLV) in farmed tilapia. Aquaculture, 487, 5155.

Suebsing, R., Pradeep, P., Jitrakorn, S., Sirithammajak, S., Kampeera, J., Turner, W., Saksmerprome, V., Withyachumnarnkul, B., \& Kiatpathomchai, W. (2016). Detection of natural infection of infectious spleen and kidney necrosis virus in farmed tilapia by hydroxynapthol blue-loop-mediated isothermal amplification assay. Journal of applied microbiology, 121(1), 55-67.

Surachetpong, W., Janetanakit, T., Nonthabenjawan, N., Tattiyapong, P., Sirikanchana, K., \& Amonsin, A. (2017). Outbreaks of tilapia lake virus infection, Thailand, 20152016. Emerging infectious diseases, 23(6), 1031.

Tattiyapong, P., Sirikanchana, K., \& Surachetpong, W. (2018). Development and validation of a reverse transcription quantitative polymerase chain reaction for tilapia lake virus detection in clinical samples and experimentally challenged fish. Journal of Fish Diseases, 41(2), 255-261.

Thanasaksiri, K., Takano, R., Fukuda, K., Chaweepack, T., \& Wongtavatchai, J. (2019). Identification of infectious spleen and kidney necrosis virus from farmed barramundi Lates calcarifer in Thailand and study of its pathogenicity. Aquaculture, 500, 188-191.

Tsofack, J. E. K., Zamostiano, R., Watted, S., Berkowitz, A., Rosenbluth, E., Mishra, N., Briese, T., Lipkin, W. I., Kabuusu, R. M., \& Ferguson, H. (2017). Detection of tilapia lake virus in clinical samples by culturing and nested reverse transcription-PCR. Journal of clinical microbiology, 55(3), 759-767. 